\title{
Hovedstrømninger i dansk film- og medieforskning
}

\section{Af Ib Bondebjerg}

\begin{abstract}
Medieforskningen er $i$ dansk sammenhung endnu ung som institutionaliseret videnskab. Ikke desto mindre kan fagets videnskabsteoretiske grundlag periodiseres ved hjolp af en rekke markante bolger: semiologien og lysk inspireret kulturkritik og offentlighedsteori $i 1970$ erne, en receptionsanalyisk mod-

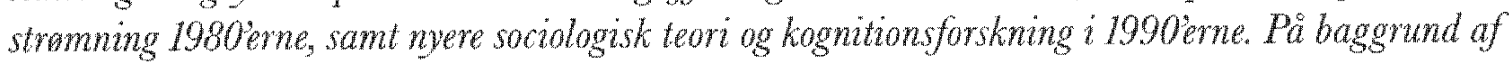
disse hovedstromninger skitserer 16 Bondebjerg kontroverseme og den teoretiske udvikling i dansk medievidenskab. Fremstillingen af disse brydninger hviler dog pà denne pointe: at der bag de markante forskelle ligger en udbredt konsensus, som udgor selve sammenhongen i dansk medieforskning. Folles for de forskllige teoretiske perspektiver er nemlig, at de på hoer deres màde saller institution/samfund, teks//estetik og modlager iforhold til hinanden. Det er imidlertid betoningen af tyngdepunktet idenne relation, der er forskellig.
\end{abstract}

Fagområdet film-og medievidenskab dakker over et relativt nyt tvarfagligt felt, som forst ide seneste 10 til 20 a r er blevet samlet og fokuseret til et egentligt videnskabs- og undervisningsfag. Det har spillet en central rolle for moderniseringen af samfundsvidenskab og især humaniora ved at rykke de moderne medier og den moderne popularkultur ud af en normativ, ideologisk dannelsessammenhreng og ind i et videnskabeligt forskningsfelt og har samtidig medvirket til at forny teori- og metodeudviklingen. Et opleg om hovedstromninger i film- og medieforskningen kan ikke påberåbe sig en lang forhistoric. Selvom der for 60'erne findes en vis forhistorie baseret pă enkelte pionerer, inden for isser presseforskning og filmforskning, så bcgynder medievidenskabens historie forst for alvor i slutningen af 60 'erne, samtidig med ungdomsoproret. Den faglige udviklings egentlige startpunkt cr et opgar med traditionsbetonede faglige dannelsestraditioner, for hvem de moderne massemedier stort set ikke cksisterede.

\section{En røst fra fortiden}

At denne sans for populwerkulturens og massemediernes udgræensning fra det akademiske ikke er en ny historie, det kan man fă et indtryk af ved at kaste et blik pă den måske forste danske medieforskers vark, P.M. Stolpes voluminose og detaljerede Dagspressen i Danmark, dens Vilkaar og Personer indtit Midten af det attende Aarhundrede. I-IV (1878-1882), et historisk standardværk om den tidlige pressehistorie, som der stadig refereres til, bl.a. i nyere pressehistoriske disputatser som f.eks. Poul Jensens Presse, penge og politik 1839 -48 (1971), Niels Thomsens Dagbladskonkurrencen 1870-1970 (1972) og John Chr. Jørgensens Det danske anmelderis historie (1994). P.M. Stolpes forskningsmassige perspektiv er, som det fremgar af forordet, praget af en optimistisk tro på oplysningsfilosofien og mediernes rolle som formidlere og brobyggere mellem forskellige lag af befolkningen:

Mellem de Frembringelser paa Literaturens Omraade, som Bogtrykkerkunstens Opfindelse har fostret, er der ingen, som i sin Udvikling har haft den Indllydelse paa Samfundet som Dagspressen. (..) Er der noget Anliggende, noget foretagende af politisk, social, kommunal, kunstncrisk, videnskabelig, industriel eller kommerciel Natur, som ikke finder Omtale der? (..) Fra den store politiske ledende Artikel, som ryster Throner og styrter Ministerier, til den lille politivenlige Anke, fra Anmaldelsen af det epokegjorende videnskabelige vark 
til Gaardsdagens Forestilling paa et Forstadstheater optrader den kritiserende, vurderende, ankende, revsende, fordommende eller rosende og anerkjendede: skabende den offentlige Mening og berende den, idet den i sig selv ubevidst optrader som Organ for Tidens dxemrende Trang, Onsker og Forhaabninger eller for dens Uvilie, Antipathi og Had (.) Man kan maaske sige, at Avisen kun bringer Kundskabens Skillemønt, men den Fattige maa lade sig noje; fik han ikke Skillemønten, fik han vel slet Intet. De store ideer, nedlagte i Bogerne, er det Avisens sag forst ret at satte i Omlob, giore dem til alles Fjendom. (Stolpe, 1878, bd. 1, p. $1-3)$

Man fornemmer et historiens vingesus i dette tidlige udsagn fra en dansk medieforsker, som på én gang har sat sig for at skildre medierne i deres historiske og kulturelle sammenhang, men som også søger at placere medierne som en central og legitim del af forskningens omräde. Medierne ses som led i moderniseringens og demokratiseringens modsatningsfyldte drama, og Stolpe vender sig imod normative, moralske forestillinger om medierne som ct på forhand underlødigt og mindre kulturelt vardigt felt.

Derved forbinder Stolpes projekt sig pä cn måde også med det kritiske projekt, som har varet udgangspunktet for dansk medieforskning, og som stadig på afgorende vis prager den brede kulturm elle og sociologiske strom i dansk medieforskning som siden slutningen af $60^{3}$ erne har varet med til at satte en dagsorden, der $i$ høj grad har bygget på en forestilling om demokratisk brobygning, kritisk analyse og på et oplysningsprojekt funderet i en lang kritisk tradition. Der går derfor ogsă en klar og lige linje til den forste kritiske medieforskning inden for de trykte medier, som faktisk dominerede en del i starten, men siden er blevet mere marginaliseret pga. de audiovisuelle mediers stigende betydning. Men allerede med Frands Mortensen m. fl.s Ikke et ord omytringsfrihed (1977) er perspektivet jo at se dagspressen i lyset af et mere generelt, historisk og aktuelt demokrati- og ytringsproblem, som forhindrer journalister og brugere af medier $i$ at fa en kritisk og anderledes journalistik og der lagges vagt pả bäde det brede historiske blik og det indgribende, handlingsanvisende. Citatets problemstilling forholder sig også til et af de foreløbigt sidste presseforskningsprojekter, Jorgen Poulsens Dagbladsprojekt (Jorgen Poulsen, m.A. 1996 og 1998), hvor perspektivet ganske klart ligger i forlangelse af Stolpes, nemlig en analyse af avisen og journalistikken udfra læesernes behov og problemstillinger som led i et demokratisk brobygnings og udviklingsprojekt. Selvom Stolpe måske på mange måder teoretisk metodisk ligger fjernt fra badde den mere cmpirisk kvantitative presseforskning som har preget Niels Thomsen og hans historiske fagfaller og den nyere kritiske presseforskning, så har Stolpes røst fra fortiden alligevel lange tråde op i den moderne medieforskning.

\section{Medievidenskaben og semiotikken}

Skal man forstå det videnskabelige grundlag for de dominerende stromninger i film- og medicvidenskaben i Danmark, sả er der to centrale indfaldsvinkler, der indgik forskellige alliancer $\mathrm{i}$ den tidlige medieforskning, som er uomgrengelige: $p a i d e n$ ene side den overvejende fransk-italienske semiologi og strukturalisme (Metz, Barthes, Levi Strauss, Eco), der lagde grunden til det udvidede tekstbegreb og den udvidede tekstanalyse; på den anden side den oprindeligt starkt tysk dominerede sociologiske indfaldsvinkel, som den representeres af Frankfurterskolens kulturkritik og Habermas og offentlighedsteorierne, og som var med til at placere medicanalysen uden for medierne selv, og som også ofte rummede et socialpsykologisk eller freudiansk perspektiv.

I modsatning til langt de fleste andre europxiske lande, er medievidenskaben stærkt forankret $i$ humaniora, dvs. i f.eks. sprogvidenskab, litteraturstudier og andre astetiske fag - og når det gælder tidlig presseforskning - også historie. Semiologien og strukturalismen forte inden for de astetisk-sproglige fag allerede $i$ lobet af 60 erne frem mod en potenticlt kulturkritisk forstäelse af tekster af alle slags (triviallitteratur, ugeblade, reklamer, tv, film etc) som tegnsystemer i samfun det. Der findes endda en cndnu lxngere historisk tradition tilbage til de tidlige russiske formalister, som via Propp og Roman Jacobsen også har haft betydning for medieforskningen, for narratologi og retorik, og som også via den tidlige filmteori går direkte ind i den moderne neoformalistiske og kognitive filmteori (Bordwell, 1985 og Kristin Thompson, 1988, se endvidere fremstillingen i Ib Bondebjergs forord til Bondebjerg, 1999).

Men det afgorende historiske gennembrud er 
givetvis 1964 og helt pracist det beromte nummer af tidsskriftet Communications (nr. 4, 1964), som netop handlede om semiologiske studier, og hvori der var bidrag bade om reklame og orn film af bla. Barthes og Metz. Fra dette nummers anlag udvikles hele den moderne semiologiske analyse af kommunikationsformer, som gør krav på at grundlagge en videnskabelig forståelse af teksters overflade- og dybdestrukturer. Det semiologiske projekt er at beskrive en rakke relativt konstante og tvaergående strukturelle trak ved tekster og kommunikationsformer, som til gengald kan manifestere sig i mange historiske og astetiske variationer, og semiologernes interesser og analyser gik kreativt og frakt på tvaers af den kendte og mere astetisk valoriserede opdeling aftekster, som indtil da havde praget de humanistiske fag. For semiologen og ideologikritikeren - ofte forenet i samme person - var kultur og kommunikation tegn, forankret i koder og konventioner, og de var endvidere forbundet med mere omfattende mytologier og ideologier, som via mediesystemerne institutionaliseredes til ideologiske og kulturelle apparater, der oftest udtrykte eller forstarkede det eksisterende samfundssystem.

Da Søren Kjorup i 1975 med sin bog Filmsemiologi sammenfattede det semiologiske projekt for et dansk publikum var vagten lagt på filmsemiologien, selvom Kjorup peger på semiologiens bredere grundlag og ogsä i forordet gør opmarksom på tendensen til at kombinere semiologisk analyse, ideologikritisk og socialhistorisk analyse. I en rakke senere arbejder er det specielt Metz'og Barthes arbejder omkring billedkommunikation og film som sprog og fortallesystem, der står i centrum. Herhjemme f.eks. Jens Tofts omfattende forsøg på på baggrund af Metz at beskrive de grundlaggende filmiske representationssystemer filmsprog, subjekt og samfund (1985) eller Palle Schantz Lauridsens to tcoretiske monograficr om netop Metz og Barthes (Schantz Lauridsen, 1984 og 1990). Det er ogsà den bredere semiologiske indfaldsvinkel til billedkommunikation, der prager en af de måske mest indflydelsesrige antologier og grundbøger Visuel Kommunikation 1-2 (Red. af Bent Fausing og Peter Larsen, 1980 ).

Men folger vi det semiologiske spor op igennem. dansk medieforskning, så er det ganske karakteristisk, at det specifikt filmsemiologiske hele tiden eksisterer side om side med en meget bredere semiologi som grundlag for medicfaget som sâdan. Analysen af medieteksterne var i den tidlige kriti- ske medieforsknings- og undervisningspraksis stierkt praget af semiologiens strukturelle modeller og tankesxt og dannede afsat for konklusioner om teksternes dybtliggende mytiske og idcologiske strukturer og deres forhold til og forankring i sociologiske og institutionelle strukturer. Udgivelsen på dansk i 1978 af John Fiske og John Hartleys Fyernsynets sprog vidner om den stæerke institutionalisering af netop denne teoretisk-metodiske kombination.

Men selvom det semiologiske projekt på mange måder har fastholdt sin betydning, således at begreber fra semiologien indgår i den elementare forståelse af, hvordan man kan aflæse og forstå massemedier i mange danske og udenlandske grundboger, så er det ligesă klart, dels, at den semiologiske analyse sjaldent har stăet alene, og at det oprindelige semiologiske projekt har modt mange modgånde bevægelser og kritik-punkter. Forsoget pa at definere mere objektive betydningsstrukturer og analysere dem i et makro-sociologisk, ideologisk perspektiv blev tidligt modt med et posi-strukturalistisk og posimoderne opgen, som specielt i 80 ernes film- og medieforskning vendte sig mod, hvad der opfattedes som en tendens til strukturel reduktionisme og forenkling. Post-modernister og post-strukturalister leder efter brud og mere komplicerede og uudgrundelige astetiske former og fanomener, både i massekulturen og avantgardekulturen, eller subkulturelle lasninger som erstatter den kritiske teoris forestillinger om dominans. Igen kan en udgivelse som John Fiskes Televi. sion Culture (1987), en bog som blev meget brugt i universiteternes medieundervisning, pege på både kontinuitet og brud. I denne bog inddrager Fiske fortsat begreber og synsvinkler fra semiologien og den kritiske teori, men samtidig placerer bogen på meget markant vis det aktive publikum som det centrale. Bogen foretager i det sidste afsnit et ganske paradigmatisk skifte med stor begrebsekvilibrisme, der har til formål at pege på betydningen af lascrnes semiotiske magt, de skjulte kulturelle ressourcer i popularkulturens mainstream produkter og evnen til hos popularkulturens brugere at vende social og okonomisk dominans og kommercialisering til kulturcl magt og mangfoldighed. Man tor slet ikke trenke pả, hvad citatet omsat til kulutr-og medicpolitik kunne fore til:

Diversity is not simply to be measured in terms of the variery of programs transmitted: diversity of readings is equally, if not more, important. Para- 
doxically, diversity of readings may best be stimulated by a greater homogeneity of programming. (Fiske, 1987: 319).

Postmodernismen og post-strukturalismen har givetvis på enkelte punkter fort til skarpsindige, xstetiske analyser ${ }^{2}$, men både som filosofisk og astetisk bevagelse, har den også været praget af mange diskutable forestillinger, der rummer en rabiat relativisme og underkendelse af fundamentale strukturers betydning som grundlag for kommunikation $o g$ forstaelse. Nar Stanley Fish i sin nu berygtede bog fra 1980 i sclve titlen spurgte Is there a text in this Class (Stanley Fish:1980), og sa at sige benxgtede tekslige strukturers betydning eller den fortsatte cksistens og betydning af genrer og narrativitet, så var den poststrukturalistiske analyse og dekonstruktions-analysen på vej mod et sort hul. Năr begreber som wsimulacrum og dermed en tomning af mediernes reference til og forankring i en ydre virkelighed (se feks. min kritik af disse tendenser i Bondebjerg, 1989) kunne begynde at florere i analyscr af dokumentarisme og fakta, så var det udtryk for en postmodernisme på vej ned ad skrapplanet og ud i det tomme rum. Fortallinger stăr så starkt som for, selvom nye former hele tiden kommer til, og virkeligheden er til stede og foregär, trods mediernes udvidede rapportering og ogede manipulationsmuligheder.

Nok sà afgorende har det imidlertid varet, at det semiologiske projekt i lobet af 80'erne og 90 'erne tog en mere social-semiotisk, pragmatisk og retorisk retning. Soren Kjorup (1994), som var med til at introducere semiologicn i 60 crne og 70 'erne har i tidsskriftet Mediekulturs pâ mange måder centrale tcorinummer fra 1994 (nr. 22), netop markeret, at retorikken og semiologien tilhorer to måske i virkeligheden konkurrerende traditioner og defineret retorikken som del af en pragmatisk erkendelsesteoretisk stromning. Samtidig slär en fornyet interesse for Peirces semiotik igennem i flere varker og i forhold til arbejdet med iser computer-kommunikation. Dels udgav Jorgen Dines Johansens Dialogic Semiasis (1993), som modstiller en mere pragmatisk og en mere traditionel strukturalistisk kommunikationstankning, og Klaus BruhnJensens The Social Semiotics of Mass Communication (1995), har som sit udgangspunkt, at der i semiologien har varet for megen fokus pă tegnsiden, det formalistiske, på teksten, og til gengald for lidt vagt på tegnenes liv i samfundet og modtagerens rolle som aktiv storrelse. En vis reformulering af denne nye semiotiks anvendelighed ikke bare for film og medier, men bredere tvarvidenskabeligt ses i cn antologi som Anvendt semiotik (Gall Jorgensen (red.), 1997) og som navnt i en rakke varker om computere og computersemiotik: Peter Bogh Anm dersen A Theory of Computer Semiotics (1990), Niels Ole Finnemanns Tanke, sprog og Maskine (1993) og en rakke antologier redigeret af Jens $\mathrm{F}$. Jensen (f.eks. Jensen, Jens F., 1990). De nye mediers større interaktivitet og den ogede vagt på andre former for kommunikation end massekommunikation synes at fremkalde nye semiotiske synsvinkler.

Fra sit grundlaggende udgangspunkt som en del af formuleringen af medievidenskabens forskningsfelt i slutningen af 60'erne har semiologien og semiotikken således, trods en vis modstand og modbevagelser, gentaget sin teoretiske ambition om at levere et grundlag for medievidenskaben her i 90 'erne. Men selvom semiologicn og semiotikken er af uomtvistelig betydning, så er 90'ernes mest markante modstrøm til denne udvikling, den kognitive film- og medieforskning (jvf. nedenfor) på delvis konfrontationskurs med disse udviklingstendenser, og specielt semiotikkens manglende forbindelse til visuel kognition og psykologi. Når der ses bort fra semiotikkens betydning inden for nyere computerforskning, så er sporgsmålet, hvor stor gennemslagskraft denne nye semiotik egentlig har i forhold til en film- og medieforskning, hvis hovedtendenser i 80 'erne og 90 'erne har varet kultur' elt $\mathrm{g}$ historisk orienteret, og hvor en ny bevagelse er på vej mod en større kognitiv-psykologisk forstäelsesramme for mediebrug og medieoplevelse. At forstå de nye medier primart via en klassisk perciansk semiotisk synsvinkel forckommer ikke umiddelbart indlysende, selvom visse grundlæggende trak ved disse mediers kommunika-tionsplatform måske nok lader sig belyse i lyset af Peirces kendte trekantmodeller i uendelige rækker. Men abstraktionen og skematikken er i mange tilfalde til at fole på i forhold til mere konkrete indholdsmassige eller konkrete psykologiske eller sociologiske studier af faktiske computergenrer og faktisk computerbrug.

\section{Medieforskningen og den ideologikritiske tradition}

Semiologiens betydning for udviklingen af den danske film- og medicforskning udgor kun det ene ben i den dobbelte bevagelse, som forte til institu- 
tionaliseringen af et egentligt mediefag. Den anden bevagelse var allerede anlagt i semiologien selv, som studiet af tegnenes liv i samfundet, som allerede Saussure pegede på, og som 60'ernes og 70 ernes film- og medieforskere tog fat pa, idet de kombinerede den strukturelle analyse med bredere sociologiske indfaldsvinkler på medierne rolle for ideologi, i socialhistorien og i forhold til dominerende eller alternative offentlighedsformer. I denne kombination af semiologi og sociologi, bliver den karakteristiske tværfaglighed i instititutionaliseringen af et moderne dansk mediefag synlig. Det er ikke bare en intern, humanistisk tvarfaglighed, hvor sprogfag, litteraturfag og historie kommer $\mathrm{i}$ berøring, men ogsa en tvarfaglighed, som fra starten sprengte den traditionelle humanistiske fag-og emneopfattelse. Langt storstedelen af de medieforskere, der var med til at grundlagge fagområdet $i$ slutningen af 60 'erne og begyndelsen af 70 'erne, kom fra de litterare, xstetiske og sproglige fag, men deres indfaldsvinkel var en grundlacggende sociologisk opdagelse af underprioriterede eller helt udgransede dele af disse fags traditionelle emneområde, kombineret med et kritisk opgor med en blot nykritisk fortolknings-tradition overfor tekster.

Videnskabeligt laber det semiologisk-strukturalistisk projekts udvidede tekstbegreb således sammen med offentlighedsteori og marxisme, som i mere direkte sociologisk forstand så tekster og medier som del af et socialt, institutionelt og klassemassigt perspektiv. Den ideologikritiske indholds- og institutionsanalyse fra 70 crne kastede sig bredt og med tvarfaglig dødsforagt ud i analyser af både radio og $t$, film, trykt presse og journalistik, ugeblade og litteratur og blade for børn og unge. En omfattende tcori-import og teori-bearbejdning, fortrinsvis med rodder i en tysk Frankfurter-skoletradition, fremstillinger og analyser af socialhistoriske forhold og kvalitative oftest strukturalistisk inspirerede medicanalyser vidner her om cn kreativ »gründer-tid«, hvor sclvfolelsen som kritiske paradigme-dannere, bestemt ikke fejler noget.

Mens den tidlige presseforskning f.eks. typisk så sig selv som en empirisk funderet kommunikationsforskning (jvf tidligere omtale af f.eks. Niels Thomsen), og arbejdede med store kvantitative, empiriske datamasser, så var det et stăende numm mer i 70'ernes introduktioner til medieforskning og medieteori, med henvisning til amerikaneren Merton (1957) at sondre mellem den mere »admi- nistrative og »kritiske forskning brugt Merton-citat hed det henholdsvis: (om den empiriskc/administrative forskning): "Vi ved ikke om det vi siger er sarlig interessant, men i det mindste er det sandt «; (om den kritiske medicforskning): "Vi ved ikke om det vi siger er sandt, men $i$ det mindste er det interessant af den tidlige medieforsknings metaforiske slagnumre, praget af et vist oprørsk letsind $\mathrm{og} \mathrm{cn}$ vis metodisk hybris, som heldigvis ikke altid modsva. redes af den faktiske forskning. En andet af periodens metaforer var Oskar Negts udsagn om, at mmedieforskningens centrum ligger uden for medierne selve, et udsagn som netop legitimerede den brede sociologiske indfaldsvinkel, og som kompletterede semiologiens mere interne tekstfom kusering og dermed mere bastant gav krop til Saussures forestilling om stegnenes liv i samfundet $\ll$.

Begge disse metaforiske sentenser står i en af de boger fra 70 'erne som signalerede feltcts institutionalisering, Michael Bruun Andersen og Jorgen Poulsen antologi Mediesociologi. Introduktion til massekommunikationsforskning (1974), hvor Frankfurterskolen og ideologikritikken stod i centrum. Bogens fortrinsvis udenlandske og fortrinsvis tyske bidrag dakkede krikik (fortrinsvis af andre former for kommunikationsvidenskab), teori (specielt forholdet mellem okonomi, klasseanalyse og medier) og analyse, hvor en af periodens bedst skrivende og mest klare analytikere, Peter Larsen, var helt alene - og endelig et serviceafsnit om empiri, som henviser til hvor man kan få empirisk viden om danske massemedier. Empirien var altså ikke bandlyst i den kritiske teori-- det var perspektivet i brugen af empiri, der stod til diskussion.

Peter Larsens to analyser af henholdsvis DR's TV-avisen og tv-serien McCloud (Larsen $1974 \mathrm{og}$ 1974 a) viser den klassiske, kritiske fiktions- og fakta-analyse, när den er bedst. Peter Larsens semiologisk-ideologikritiske analyse af TV-avisens udsigelsesstruktur skarer ind til det strukturelle, udsigelsesmæessige og idcologiske ben:

Man kan sporge, hvorfor institutionen TV har valgt denne udsigelsesstruktur som ramme om sin nyhedsformidling Svaret på dette sporgsmål er naturligvis, at der er snæver sammenhxng mellem statens bærende ideologi og stats-fjemsynets mest sofficielle produkt« ... tv:a's normalfortalling (cr) ... jo samtidig model for de myter, som det reprasentative, parlamentariske system fortaller om 
sigselv-de myter hori det hedder, at der i det kam pitalistiske samfund ikke eksisterer klasser, men kun mere eller mindre sammenhangende gupper - at der ikke eksisterer klassemodsatninger, men kun kommunikationsproblemer, som lader sig lose ad forhandlingens og samtalens vej ved hixp af det rationelle argument, uden at grundlaggende samfundsmassige forhold behover andres. (Larm sen, 1974: p. 290 )

Selvom der mangler en del nuanceringer og mellemregninger i en sadan semiologisk-ideologikritisk analyse, set med den nyere medieforsknings øjne, sa formulerede artiklen en rakke centrale og vasentlige sporgsmal og analytiske perspektiver. Den samme analyse og pointe blev allerede to ă tidligere fremanalyseret $i$ en af de forste storre medieafhandlinger pa dansk, Frands Mortensens Communikationskritisk analyse of 22-radioavisen. (1972). Frands Mortensen, som da var amanuensis pä Arhus Universitet og havde skrevet guldmedaw jeafhandling 1970 om s Satningsemnet og dets anvendelse i nyere dansk lyrk sproglige analyse-evne pä en noget anden opgave. Han foretager en strukturel analyse af 10 radioaviser med henblik på at analysere ideologien bag og give svar pá om Radioavisen or neutral, hojreoricnteref eller venstreonienteret.

Den kritiske analyses forhold til empirien og til laserne, modtagerne var et af de forhold som den sencre empriske receptionsforskning $\log$ op, da en nyere generation 80 erne kom til og foretog et opgor med dele af den kritiske tradition. Men trods den beretigede kritik, som her blev fremfort, og som jeg skal vende tibage til, sá var hverken empirien - som allerede nevnt - eller modtagerne ganske fravarende. Det ser man i den bog, som historisk set má karakteriseres som den moderne danske medicforsknings forste hovedvark, den kollektivt skrevne Sondags BT. Rapport on en suces (Bolvig, m.n. 1971), hvor det igen var Arhus der slog til, under ledelse afJohan Fjord Jensen. Bogens tilblivelse, som et kollektivt laere-studenter forsk ningsprojekt erisig selv tidstypisk, og blev aret efter fulgt op af kobenhavner-siden med Udrigten fra det hoindelige wnivers. En analys of Ena (Mollor, m. 1972) og igen aret efter fra Arhus af den forste store ideologikritiske tegneserie-analyse Tegneserie En eksonsiomshistorie (Orvad Andersen, 1973).

Det er den symptomale, semiologisk inspirerede analyse af en stor tekstmasse der dominerer, og tekstemes dybdestrukturer skrives ud i omfat tende modeller. Men i det mindste er tekttlasningerne grundige og histonisk og sociologisk perspektiverede og empiriske data om bade udbredclse, stokategorier og i en rakke tilfalde ogsă laserprofiler indgar faktisk, ogsa i Trands Mortensens radio-avis bog, hvor et af de sidste afsnit faktisk hedder Modtagerens opfattelse af kommunkationere (Mortensen, 1972: 208-216). Selvom bogens hovedsigte fremstilles som dette at analysere de faktiske ideologiske strukturer i teksten, să opstilles der en metode, som gár ud pá at konfrontere afsenderens opfattelse af kommunikationen med modtagerens, idet analysen dog viser at oplattel sen af modtagene har meget lidt empiri at bygge pa (Mortensen, 1972: 208 og 217). Men hverken afsenderinstitutionen eller modtageren er altså fravarende i denne tidlige ideologikritiske analyse. Ogsa Sondags BT-bogen rummer et bredt hel hedspespektiv der inddrager bade afsender og institution, tekstog modtagere-omend med forskellig vagtning. Forholdet til empiricn fomuleres endda $\mathrm{i}$ forordet i netop cn langt mindre lossluppen stil end den holdning, som máske i perioden ofte i polemikker kom til udtryk i forhold til den empiriske medieforskning:

Vibetragter denne rapport som led i opgoret med den positivisme, der tror sig vardifri, men ogsa som et forsog pa at komme ud over de former for antipositivisme, der stiller sig hinsides erkendelsesmassig kontrol. Men forst og fremmest har hensigten med rapporten veret, at den skulle bruges. Den er et stykke ideologikritik. Den analyserer en herskende ideologi. Og den udrrykker en kritik af det herskende i ideologien. (Kirsten Bolvig, m, A., 1971: p. 10-11)

Modtageranalysen var altså, frods det senere eftermale, faktisk med i et oller andet omang i den tidlige, kritiske medieforskning, endog ogsá iform af empiriske modtager-data, omend ikke fremkaldt ved egne, kvalitative interviews. Derfor lorblev opfattelsen afleseren eller modtageren da ogsa enten et kvalitativt type-portrat baseret pa kvantative data, den indskrevne laser i den tekstige strukturlasning, eller den socialpsykologisk for staede storrelse, hvis behov og interesser blev misbrugt eller fordrejet al medieme. Modtageren var ikke loftet frem som et starkt markeret selvstandigt, sociologisk-empirisk felt, selvom det var der bade empirisk, tekstigt, sociologisk og ogsa ind imellem psykologisk. Generelt var analysetendensen, saledes som bagsideteksten pä det udgivne 
speciale, som senere skulle blive til den første danske doktordisputats inden for den kritiske medieforskning, Kirsten Drotners Drengemagasiner - Magasindrenge (Drotner, 1977 og 1988) siger det:

.. det er mit mål at spore hvorledes sendringer inden for den kapitalistiske produktionsmåde satte sig igennem bevidsthedsmassigt som en stigende ideologisk inderliggerelse i litteraturen - altsa en mere indirckte form for påvirkning « (Drotner, 1977: bagsidetekst).

Det tvarfaglige opbrud inden for de ctablerede fag markeres udover disse eksempler på tidstypiske og eksemplariske idcologikritiske analyser af bredere institutionshistoriske analyser $\mathrm{i}$ et offentlighedsteoretisk og astetisk-kulturelt perspektiv. Det galder min egen Proletarisk offentlighed 1-2 (Bondebjerg, 1976-78), Bent Fausings Fascinationsformer. Estetikog medier under fascismen og i socialstaten (1978), Anker Brink Lunds Magten over DR (1976) og măske ikke mindst Morten Giersings omfattende studie af amerikansk tv TV i USA (1982), som tager hele vejen rundt: medieindustrien og institutionerne, program-historien og den internationale programeksport, $t$-forbruget og $t v$-seeren, og som dermed forbinder både sociologisk empiri, xstetisk indholdsanalyse og modtagerperspektiv, omend stadigvak som en kombination af kvalitativ indholdsanalyse, visse kvantitative seerdata og socialpsykologisk funderede betragtninger over f.eks. seriers funktion i forhold til fundamentale seerbehov.

Man kan således sige, at det tværfaglige opbrud i den ideologikritiske periode forsoger at fastholde et ganske omfattende helhedsperspektiv, hvor dog det makro-sociologiske og tekstlige perspektiv så absolut stod i centrum. Det galder ogsa for de tilsvarende tendenser indenfor filmanalysen i 70 'erne, dels i den legendariske og i visse kredse herostratisk berømte antologi Filmanalyser. Filmen ihistorien (Michael Bruun Andersen, m.fl, 1974.) og i Levende billeder of Danmark (Troelsen (red), 1980).

Bevagelsen i denne tvarfaglige periode ud af de traditionelle astetiske og humanistiske fag ledsages uden for forskningen af en betydelig indsats for etablering af feltet som et padagogisk-gymnasialt fag, f.eks. med Borup Jensen \& Pedersens Billedmedier (1973), Olivarius m.f.(ed) Massekommunikation og Seeberg Friis, m.fl.(ed) TV-analyseTeori og metode til medieundervisning og kritik (1976). Her formidles den ideologikritiske, socialhistoris- ke og semiologisk inspirerede medieanalyse ud i det bredere undervisningssystem.

\section{Cultural studies og modtagerforskning}

Hvis 60'erne og 70 'erne står i semiologiens og ideologikritkkens tegn, så stăr 80 'erne til gengald $i$ cultural studies traditionens og modtagerforskningens tegn. Fra 90'erne ses til gengald også en bredere historisk forkning med institutionssociologiske og genrepriegede studier. Samtidig udfordres den traditionelle humam nistiskc approach af kognitionsforskningens markante fremgang internationalt, og specielt inden for filmforskningen også nationalt.

Omkring 1980 er Film- og medieforskningen ved at blive voksen og selvstandig og udskillelsen fra de oprindelige moderfag tager fart. $\mathrm{Pa} K \mathrm{KU}$ smelter filmvidenskab og Center for massekommunikation sammen til Institut for Film og medievidenskab i 1988, og tilsvarende institutionsdannelser sker på RUC, og i Odense, Aalborg og Århus, med forskellige profiler. I Arhus således gennem en integration med Informationsvidenskab. 80'erns instititutionaliseringshistorie er imidlertid snarere en bevagelse mod en situation, hvor alle institutioner i det vasentlige på en eller anden måde genstandsmassig omfatter både traditionelle massemedier og nye medier, og hvor der ikke er tale om markante forskelle i teoretisk-metodisk orientering, omend nok en vis forskel i faglig profilering.

Det er af betydning for fagomraidets modning og interne dialog, at et falles tidsskrift, Mediekultur, fra 1981 kan udgøre et national fokuseringspunkt, at den nordiske organisering med både sit skandinaviske og engelsksprogede blad Nordicom Nyt og Nordicom Review placerer dansk medieforskning internationalt $o g$ at en betydelig international publiceringsbolge og integration i den internationale forskerorganisering og dens tidsskrifter slår igennem. Inden for denne internationalisering ma det forudses, at de kommende år byder på en starkere udbygning af den europaiske dimension, jvf. den europaiske medieforskerorganisering, som så smăt er ved at opstå, og i lyset af det store, europxiske ESF-projekt inden for medieforskning Changing Media-Changing Europe, som er sat igang fra efteraret 1999 (ledet af Peter Golding, UK \& Ib Bondebjerg, DK). Men i det hele taget kendetegnes 
90 'eme af en rakke store, tvargåcnde og internationalt orienterede forskningsprojektet: Teoriudvikling inden for visuel kommunikation (KU, 1991-1993), TV-restetik (1995-1999, AU \& AAU), Medierog Ungdomskultur (KU, 1995-1999), Den Billedskabte virkelighed (1996-1999, KU), og pa det seneste cn rakke Humanisliske IT og multimedie-satsninger (både på $\mathrm{KU}, \mathrm{AAU}, \AA \mathrm{A} U \mathrm{~m} . \mathrm{l}$.).

Basis for denne konsolidering og institutionalisering af film-og medieforskningen var en rakke betydelige teoretisk-metodiske nyudviklinger og ogsả en betragtelig konsolidering af den mediehistoriske grundforskning, dvs. en etablering af en slags mediehistorisk dannelsestradition, der etablerede stofomrandet som et bảde historisk felt og et teoretisk felt. Man kan nesten symbolsk sige, at overgangen fra den ideologikritiske periode til denne naste fase kan ses i de to hidtil storste historiske projekter af betydning for udviklingen af en humanistisk medieforskning. Udgivelsen af Dansk Litleraturhistorie 1-9 (Fjord Jensen, m.fl.1983-85) er afslutningen på en epoke, hvor medieforskningen befinder sig inden for en traditionel humanistisk fagramme, som imidlertid totalt omdefineres, säledes at litteraturhistorien også bliver popularkulturens og mediemes historie, og således at teksterne og medierne indsattes i en bred social- og kulturhistorisk ramme. Smá 10 àr senere er nogle af de samme personer, suppleret med en lidt yngre generation af mere receptionsorienterede medieforskere med bag Dansk Mediehistorie 1-3 (Bruhn Jensen, m.fl. (red), 1996-1997), hvor medierne er udskilt fra sin tidligere fagramme og er blevet et historisk objekt i sig selv med sin egen teori og metode. I sit forord peger hovedredaktoren Klaus Bruhn Jensen diskret på receptionssynsvinklen:

Umiddelbart ser det ud, som om kommunikationens indhold ligger klar til brug inde i de enkelte meddelelser. Men som alle mediebrugere ved, ligger der som regel ogsă medddelser mellem linierne, som man selv mả hente frem. I det helc taget er det kun i kraft af deltagerne i kommunikationen, at selve meddelelsen făr mening. (Klaus BruhnJensen (red), 1996: p. 19).

Men selvom Dansk Mediehistorie bestraber sig på via cases og tvargåcnde temaer, ved inddragelsen af også udenlandsk materialc at se pă udbuddet også fra modtagernes synsvinkel, så rakker mediehistorien som institutions-, kultur- og teksthistorie også pa dansk pragmatisk vis hånden bagud mod 70 'er-traditioneme. Det galder også for ct lidt tid- ligere men ligeså vigtigt intitiativ og forsøg på at skabe en faglig sammenhang, nemlig Frands Mortensen m. H.'s Mediehåndbogen (1990), hvis styrke som padagogisk opslagsvark netop cr, at det dakker medier bredt og også teoretisk-metodisk rakker fra institutionsanalyse over tekstanalyse til receptionsanalyse og med både diakrone og synkrone perspektiver.

Men introduktionen af den kvalitativt-empiriske medieforskning i 80 erne forløb ikke slet să fredeligt, som mediehistorien synes at antyde. Receptionsbolgen tog land allerede i 1984 med Anne Horts kun universitetsinternt publicerede speciale Nar kvinder ser TV - om medieforskning og reception (en sammenlignende analyse, baseret på kvalitative interviews med kvinder, om deres brug af henholdsvis den amerikanske soap Dallas og den danske tv-foljeton Krigsdotre) og fulgtes i 1986 op af henholdsvis Pittelkow og Flse F. Jensens antologi Det ukendte publikum og Klaus BruhnJensens disputats Making sense of the News. Skal man have et klart indblik i udviklingen fra den tidlige ideologikritik til 80'ernes reformerede medieforskning, sa lønner det sig f.eks. at sammenligne Peter Larsens $1974-$ analyse af tv-avisen med en rakke senere analyser. 11981 analyserer Ole PrehnTV-avisen som en underholdningsserie (Prehn, 1981), dvs. som noget nyt lagges vægt på fakta som fascination og underholdning, samtidig med at et ideologikritisk perspektiv fastholdes. I 1985 analyserer Ralf Pittelkow »Seernes TV-avis«, (Pittelkow, 1985), udsendt omtrent samtidig med hans DR-rapport TV-avisen set indefra (Pittelkow, 1986). Nyhedsanalysen bliver her orienteret både mod afsenderinstitutionen i form af en analyse af den faktiske journalistiske, sproglige og fortallemessige praksis via observation og interviews med de ansatte, via en pragmatisk-kognitiv analyse af skemaer i teksten og hos modtagerne og en kvalitativ-empirisk receptionsanalyse. Analysen har et dialogisk og reformatorisk sigte, den vil forbedre TV-avisen og samspillet mellem seer og tekst. I 1987 udgiver Klaus Bruhn Jensen DR-rapporten med samme titel, Seernes TV-atis, og her fokuseres i endnu mere radikal forstand på seernes forskellige tolkninger af journalisternes historic. Det der primart fortolkes på er sseernes tekst«, dvs, den de konstruerer i ct interview, gennem deres læsning af de udvalgte nyhedsudsendelser og indslag. Men som det er karakteristisk for den danske receptionsforskning, så anlacgger den ikke noget ensidigt isoleret blik på modtagerne. Den er bredere pragmatisk, idet den sammenhol- 
der journalisternes og seemes historie og introducerer begrebet super-temaer, som rummer nogle af de samme pointer som den kognitive medieforskning (jvf. nedenfor) lagger vegt på i samspillet mellem tekst og modtager.

Ligesom den faktisk udforte kritiske forskning ofte rummer et bredere helhedsperspektiv end man proklamerede, så rummer den nyere receptionsforskning ogsa ofte mere end en provokatorisk Stanley Fish-agtig position. Men alligevel să var sammenstodet mellem den kritiske medieforskning og den nye modtagerforskning til at tage at fole pă i slutningen af 80 'erne. I et nu forlangst udsolgt og klassisk nummer af Mediekultur med temaet Receptionsforskning i Danmark « ( $\mathrm{Nr} .7$, marts 1988) får man et indblik i donningerne bag madet mellem den hidtil dominerende kritiske medieforskning og receptionsforskningen. Her fog polemikken henover siderne.

Pă den cne side de kritiske medieforskeres bekymring for at receptionsanalysen skulle smide barnet ud med badevandet og medicanalysen helt skulle miste grebet om indholdsanalysen og forankringen i et bredere socialt og kulturelt perspektiv. En bekymring, naret af den intermationale tendens mod postmodernisme og poststrukturalisme, for at man enten skulle overgive sig totalt til interview-empiricns uendelige mikro-perspektiv, og cn total postmodernistisk opgivelse af en kritisk diskussion om kvalitet og alternativer eller blot konstanter, strukturer og falles grundlag for kommunikation.

Pá den anden side de unge receptionsforskeres berettigede behov for et vist faderopgor med en kritisk medieforskning, som talte abstrakt pă mediebrugernes vegne uden nogen sinde at studere dem mere selvstaendigt og direkte, og som opstillede kritik og alternativer, som kunne forekomme normative og uden fornemmelse for det sociologen Bourdieu definerede som distinktionens kulturelle klassekamp. Når polemikken blev skarp, så var det fordi der $i$ hvert fald $i$ dele af modtagerforskningens udspil var Stanley Fish-agtige formuleringer og postmodeme relativistiske markeringer. Kim Schroder formulerede (Schroder, 1988) således helt postmoderne og relativistisk sin tese om et skift fra tekst til publikum, hvor tekstens kvalitet for så vidt bliver ligegyldig, fordi det er oplevelsen der er det centrale, og den er forskellig og kulturelt relativ Dallas kunne være lige så godt som Shakespeare, hvis modtagerne syntes det. Pà samme máde forte også Klaus Bruhn Jensen an i en polemik, som- stillet overfor den kritiske teoris skepsis overfor en for radikal drejning mod et receptionsperspcktiv ironisk og med intertextuelt hip til Jerry Manders gamle forslag om at afskaffe tw:, Fire argumenter for at afskaffe den empiriske receptionsforskning«, som artiklen hed (BruhnJensen, 1988).

Mit eget bidrag til dette temanummer, med en vis forhojet temperatur $\mathrm{i}$ dansk medieforskning, hed $»$ Kritisk teori, astetik og receptionsforskning (Bondebjerg, 1988), men selvom det er en polemisk artikel mod visse tendenser i den nye receptionsforskning, sả rummer den også en klar anerkendelse af en ny dimension i medieforskningen, som svarer til den reelle udvikling af en bred kulturel stromning inden for film og mediestudierne, som fra 80 'erne bragte forskningen ud af den mere abstrakte semiologi og ideologikritiks dodvande. I lobet af 80 erne bliver medieforskningen til en bred kulturforskning, som både omfatter institutionsanalyser, astetiske og genremassige analyser og forskellige typer af modtagerstudier. Der foregår en vis specialisering, men som samlet forskningsindsats fastholdes det helhedsperspektiv, som langt hen ad vejen har vaeret dansk medieforsknings styrke.

I denne periode skifter den internationale orientering til i hojere grad at hente sine inspirationer i en engelsk cultural studies tradition og den nyere amerikansk-engelske sociologi, med Bourdieus kultursociologi og livsstilsanalyse, som et enkelt rransk strejf. Udviklingen går fra feks. Stuart Halls klassiske, semiologisk inspirerede "Encoding-decoding-modek (Hall, 1980), via David Morley empiriske receptionsanalyse pa basis af denne model i The Nationveide Audience (Monley, 1980) til Ien Angs nu klassiske studie af Dallasbrugere og melodramatiske folelser (Ang, 1985) og udvikler sig endelig også i denne periode over i en mere etnografisk orienteret tradition.

Denne tendens sattes tydeligt på dagsordenen i Kirsten Drotners artikel i Medikulturs temanummer om medieetnografi (Drotner, 1993), som en bevagelse mod en bredere undersogelse af folks hverdagskultur og mediekultur og mediebrug som del af denne, baseret pä observationsstudier. Medieetnografiens gennemslag som metode i 80 'erne og 90 'eme er en folge af den zendrede opfattelse af mediemes rolle og modtagerne og en folge af opdagelsen af at ogsă ens egen kultur kan betragtes etnografisk: vi lever i et i stigende grad etnisk opsplittet og multikulturelt samfund. Medieetnografien sager mod forståelse af denne plurali- 
tet $\mathrm{i}$ det kulturelle og mediekulturelle monster. I en rakke studier, som typisk knytter sig til bl.a. ungdomskultur eller til kønskulturer bliver den mediectnografiske forskning til forskning snarere i en bestemt gruppe af menneskers kultur eller mediebrug og ikke en bestemt genre og et bestemt medie.

Eksemplerne er Drotners egen undersegelse At skabe sigselw 1991, som er baseret pä bla. unges brug af video, der så udfoldes til et bredere ungdomskulturelt portrat, Birgitte Tuftes disputats Skole og medier (1995), som inddrager den padagogiske brugsog kultursammenhang, eller Karen Klitgaard Poulsens Beverly Hills 90270-Soaps, ironi og danske unge (1999). Det er en bog som på mange måder rummer de karakteristiske trak for den integrerede kultur-, tekst og modtageranalyse, som erkarakteristisk for $90^{\prime} \mathrm{ernes}$ medieforskning: Den gennemforer băde mere astetiske, genremassige analyser, ser på seriens konkrete produktionshistorie, analyserer mediekredsløbet omkring serien og diskuterer - bl. a. baseret på unges stilcskrivning - reception og brug af serien.

\section{Sociologiens genkomst: institutionsanalyse, globalisering og nye medie- og interaktionsformer}

Kulturstudierne i den moderne medieforskning er i den linje, som her er trukket frem, ikke identisk med modtagerforskningen, og slet ikke med de mere rabiate og relativistiske sider af modtagerforskningen, som is har eksempler pá. Tvartimod forer 90 'ernes medieforskning til en slags udvidet eller integreret cultural studies perspektiv som omfatter bade institutioner, tekster og modtagere. Samtidig viser 90'erne også en betydelig grad af tilbagevending til sociologiske traditioner, som bevager sig vak fra både modtagerforskningens kulturelle mikrostudier og den ideologiske makro-analyse, som pragede ideologikritikken. Hvis den ideologikritiske tradition tog udgangspunkt i teksterne og derfra trak vidtgående konklusioner, mens omvendt 80'ernes receptionsforskning i hvert fald proklamerede at kunne udlede alt fra modtagerens brug af teksten, så satter den nye sociologiske tradition igen sociale institutioner og handlinger på dagsordenen, men med fastholdelse af estetiske og progamflademæssige analyseperspektiver.
Re-integrationen af en fortrinsvis engelsk-amerikansk sociologisk tradition med f.eks. Anthony Giddens (1984 og 1992), Erwin Goffmann (1992), Joshua Meyrowitz (1985) og John B. Thompson (1995) markerer en social dimensions genkomst og en fornyelse af både institutionsanalysen, genreog tekstanalysen og en revidering af massemediernes rolle i dels globaliseringsbilledet, $\mathrm{i}$ forhold til offentlighedsstrukturen og i forhold til nye mere intime og interaktive medier og medicformer, der antaster traditionelle massekommunikationsformer.

Den kritiske teori så typisk på sociale og tekstlige strukturer som noget determinerende for individers opfattelses- og handlemuligheder. Modtagerforskningen tenderede omvendt til at overspille modtagerens frie handle- og fortolkningsrum. Giddens peger med sine begreber om strukturation og institutioner som handlemassig ressource på et langt mere gensidigt forhold mellem struktur og handlen: medieinstitutioner og deres indbyggede genrer er pä engang en slags matericlle og mentale ressourcer, som for bådc afsendere og modtagere stiller nogle handle- og fortolkningsmuligheder til radighed, der ikke bare fungerer som begrensende og determinerende, men også som et mere åbent rum, hvor der er plads til forandringer, fortolkninger og refleksiv brug af de kategorier, roller og skemaer som institutionelt styrer og regulerer institutioners og handlingers rammer. Mest eksemplarisk er denne Giddens og Goffman inspirerede medieforskning foreløbig på dansk udfoldet i Stig Hjarvards seneste bog $T V-n y$ heder $i$ konkurrence (1999) der viser forandringerne tv-nyhederne som genre siden 1960 og er et frugtbart eksempel pả en ny forståelse af forholdet mellem en medieinstitution, de grundlaggende genremessige konventioner og de forandringer i diskurser og kommunikative relationer mellem afsender og modtager, som folger af opbruddet fra cn monopoliseret kultur. Det er en kritisk analyse, som undgår de faldgrupper som hedder enten ideologikritisk determinisme eller modtagerorienteret relativisme.

En rakke af disse mere kulturelle og sociologiske studier knytter sig ikke mindst til forandringerne i det tv-historiske landskab i lyset af monopolbruddet og globaliseringen og retter sig enten mod specifikke genrer eller bredere tendenser. Det galder genremæssigt for min egen kultur- og institutionshistoriske undersøgelse af $\mathrm{t} v$-fiktion Elektroniske fiktioner (1993), som ganske vist ikke er 
direkte inspireret af den nye sociologiske bolge, men representerer den brede kultursociologiske analyse med det xstetiske markant i centrum som omdrejningspunkt. Fornyelsen galder i hojere grad for Stig Hjarvards Internationale tv-nyheder (1995) den fornyelse af tv-analysen som gor sig galdende i Søndergaard \& Hjarvards Nursyn pífjemsyn (1988) og Henrik Sondergaards egen DR $i$ to konkurrencens tidsalder (1994). For Sondergaard og Hjarvards indsats er der tale om en analytisk fornyelse i kombinationen af omfattende programfladeanalyse med institutionsanalyse og en rakke teoretiske fornyelser, der netop integrerer nyere sociologisk analyse $\mathrm{i}$ forståelsen af de kommunikative forandringer, som preger forholdet mellem medieinstitutioner og modtagere. Samtidig or denne nye sociologi praget af en i forhold til den tidlige ideologikritik langt mere udviklet og diskuterende brug af bảde kvantitativ og kvalitativ empiri.

Den internationale og nationale tendens til en ny sociologisk medietradition er aftedt af et oget behov for at kunne bearbejde de omfattende institutionelle, teknologiske og dermed ogsả astetiske opbrud vi ser i den aktuelle medieudvikling. Den nationale public service kultur og ogsa den nationale filmkultur står overfor helt nye globale udfordringer, hvor nye medier er godt på vej til at underminere den mere traditionelle offentlighed og mediestruktur, som den kritiske teori opstod i. Der er i denne situation behov for en forskning i medier, som Stig Hjarvard for nylig (se Hjarvards indlag i dette nummer) har kaldt for sen usentimental $\mathrm{og}$ uhildet sociologisk og kulturhistorisk forskning«, hvor man ikke begrader globaliseringen og tabet af den nationale kultur og identitet som den naturlige kontekst. Globaliseringen har lange i realiteten vacet en selvfolgelig kontekst for film og medier, ikke bare som de multinationales dominans, men også som en ny fase af informationssamfundet, hvor nye netværksstrukturer og mediekonfigurationer vil dukke op. Det stiller ogede krav til den teoretiske og metodiske pracision og forståelse af mediebilledet. Men udviklingen viser også, at der ikke er nogen grund til globaliserings-hysteri eller overdrevne forestillinger om, at den nye medieteknologiske udfordring og det nye mediebillede i sig selv stiller krav om en total forandring af medieforskningens teorier og metoder. Der er dels ikke nogen principiel modsatning mellem at vi både lever nationalt, regionalt og globalt, og at der dermed stadig er behov for analyser på forske- lige niveauer. I forhold til vores nye mediebillede vil der ogsă stadig vare bchov for at kunne besvare nye sporgsmål med gamle prøvede perspektiver, teorier og metoder, der - ganske vist hele tiden bør justeres og fornyes - men som både omfatter xstetiske, sociologiske, kulturelle og psykologiske perspektiver.

Derfor er det mäskc ikke noget tilfalde, at en af reprasentanteme for den nye sociologiske retning, Stig Hjarvard, ser et vist samspil mellem bla. kog. nitionsforskningen, retorikken og den nye medicsociologi. I forordet til Mediekultur nr. 22 taler han netop om de falles trak:

Fremfor at anskue kommunikation som ind-og afkodning af tegn forstås kommunikation i sammenhang med et begreb om handlen: sociologien ser kommunikation som en form for social interaktion, retorikken fremdrager et sproghandlingsperspektiv og kognitionsforskningen ser forstielsen af visuelle tegn ud fra en model, hvor sansning, folelse og tenkning indgår $\mathrm{i}$ en integreret helhed med handling som en central strukturerende faktor (...) kommunikativ forståelse og handlen etableres gennem en rakke operationaliseringer afkulturelle og universelle handlingsskemata, sociale og mentale » tommelfingerregler « for adakvat forståelse og handlen. (Hjarvard, 1994: 4).

\section{Kognitivisme og kulturalisme: modsætninger eller komplementæe storrelser?}

Ser man tilbage over de seneste 30 års danske medieforskning, så falder det i ojnene, at selvom dele af både film- og medievidenskaben har rummet socialpsykologiske, freudianske eller lacanianske dimensioner i mere eller mindre spekulative udgaver, så har selv de såkaldte modtagerstudier varet blottet for en mere dybtgående psykologisk dimension, der var forbundet med viden om de nyeste tendenser iden del af forskningen. Netop denne side af medieforskningens tværfaglige ballast har varet relativt marginal. Derfor er denne side af mediereceptionen, og dermed det kognitive og emotionelle grundlag for medicoplevelser, en af de fremtidige tvarfaglige udfordringer. Ligesom der er brug for reviderede sociologiske teorier og metoder, sả er der også brug for at få skabt et revideret psykologisk fundament for den måde mediebrug og medicastetik knytter sig til fundamentale 
psykiske strukturer. En sådan forankring er en del af vaccinen mod tendenser til at lade sig forblaende af den teknologiske udvikling og forestillingen om en helt ny mediekultur.

I en presentation af den kognitive medieanalyse etablerer Torben Grodal (Grodal,1994) en bro mellem 60'ernes strukturalistiske teorier om fortallestrukturer og udsigelsesstrukturer og den nyere kognitive film- og medieteori og analyse: strukturalismens sogen efter basale strukturer i tekster svarer til de mentale modeller og strukturer, som kognitionsforskningen nu lægger frem, baseret på en starkt øget forståelse af det kropslige grundlag for kognition og folelser. Her er der tale om en forskning, som lagger vagt på de psykologiske oplevelses- og folelsesmonstre i film og medier, som i hvert fald ikke udelukkende er historisk og kulturelt bestemte, men som ikke nødvendigvis bor forstås som i modstrid med den dominerende kulturelle og historiske forskning, som ellers har praget 80 'crnes og 90 'crnes danske film- og medieforskning.

Den kognitive forskning har fremfort en meget hård kritik af dele af den kulturalistiske og især poststrukturalistiske, postmoderne og psykosemiotisk inspirerede analyse, som har harget især dele af den angelsaksiske filmforskning - og med god grund. Men kognitionsforskningens synsm punkter og hidtidge resultater er ikke uforenelige med de hovedstromninger i dansk medieforskning, som primart har holdt fast i at ville undersage samspillet mellem grundlaggende tekstlige strukm turer, genrer og konventioner og så specifikke historisk-kulturelle forudsatninger for eller brug af disse.

Kognitionsforskningens synswinkel erstatter elm ler ophaver ikke specifikke xstetiske, historiske eller kulturelle studier af medicr og medietekster, men tilbyder en măske klarere og bedre funderet forståelse af de fundamentale strukturer og genrer, som megen kommunikation er baseret på, og som for visse tings vedkommende (bl.a. visuel perception) er temmelig universelle og for andres vedkommende er meget stabile henover kulturer og historiske epoker, f.eks. basale fortællende strukturer og elementare genrer. Det var sådan set den pointe, som den semiologisk inspirerede medieforskning tog sit udgangspunkt $i$, men som har varet på vej til at blive tabt delvis undervejs, i relativismens og postmodernismens delvise solformørkelse. Kognitionsforskningen tilbyder en ny tvarfaglig indgang til forstäelsen af disse funda- mentale strukturer, men underminerer ikke dermed behovet for konkrete kulturelle og astetiske analyser. For disse basale strukturer modes og brydes i konkrete tekster, pä konkrete historiske og kulturelle betingelser og $\mathrm{i}$ hovedet eller interaktionen mellem konkrete mediebrugere, som både har fellestrak og derudover er meget forskellige.

Der har igennem 90'erne været megen hul våbenklang i sammenstødet mellem humanistiske kulturstudier, æstetiske analyser eller modtagerstudier og kognitionsforskningens frontfigurer. Sådanne sammenstod og markeringer af forskelle er frugtbare for videreudviklingen af en videnskab, men kun hvis man anerkender et falles projekt, og hvis man reelt forsoger at udvikle tvarvidenskabelige metoder og begreber. Det har hidtil varet medieforskningens styrke, og $\mathrm{i}$ det nye årtusinde bor dette træk bevares, så vi i højere grad ser en dialog, hvor humanistiske kulturstudier møder de kognitive studier som udgor en af fremtidens store tvarfaglige udfordringer. Som bl.a. den unge engelske filmforsker Murray Smith har udtrykt det:

den kognitive Film og medictcori (.) komplementerer historisk fokuserede studier af specifikke, socialt konstituerede modtagere. Skema-teori tillader os at fylde mere eller mindre historiske og kulturelle detaljer på (.) Man kan starte med en meget abstrakt modtager og de mest minimale kompetencer til at forstå en fortzlling. For at forstå mere specifikke publikumsgrupper og deres reaktioner er det så nodvendigt at forstå de kulturelle modeller de bruger i deres forstålse. (Murray Smith, 1995: 65, min oversattelse).

\section{Fremtidige udfordringer for dansk medieforskning: Sammenfatning og perspektivering}

Vi er uden tvivl på vej mod en langt mere globaliseret mediekultur end vi tidligere har set, og vi or på vej mod en situation, hvor de såkaldte massemedier ikke langere vil vare så dominerende, som de har varet $i$ anden halvdel af det 20.årh. Digitalisering og tcknologisk konvergens cr ikke utopiske fremtidsvisioner for medieindustrien, men en begyndende virkelighed for rigtig mange mediebrugere, selvom det vil tage år for springet or gennemfort, og selvom mange teknologiske forudsigelser givetvis vil slả fejl. Forudsigelserne om bo- 
gen, fortallingens, radioens, biograffilmens og nu også tv-broadcast-kulturens undergang vil formodentlig vise sig at vare lige sa overdrevne, som de altid har varet: mediehistoricn viser, at medierne ofte finder sig en ny plads, selv når medieteknolom giske kvantespring bringer nye muligheder.

Hvis medieforskerne lader sig lokke for meget af forestillingen om, at de nye medier kraver en helt ny medieforskning, să har vi for alvor skabt problemer for fremtidens medieforskning. Det er medievidenskabens opgave - som altid - at fastholde ct bredt videnskabeligt fundament for besvarelsen af alle de sporgsmål som en ny medickultur rejser, men at gore det pä basis af en solid historisk viden og en rakke fundamentale teoretiske dimensioner og indsigter som styrer vores fokus på medierne, snarere end at tillade teknologien og sette dagsordenen. Samtidig er det sådan, at selvom globaliseringen i fremtiden vil skabe nye kulturpolitiske udfordringer for en medie- og kulturpolitik, som blev skabt i en nationalstatslig regi, så overflodiggores medieforskningens historiske og aktuclle rolle som led i dannelses- og kulturkampen ikke, tvartimod. Bảde udadtil i et europaisk og globalt perspektiv er der grund til nedadtil $i$ uddannelsessystemet at arbejde for etableringen af et nyt mediefag som et af de centrale dannelsesfag i fremtiden. Der er også behov for at fastholde medieforskningens kritiske betydning som producent af viden, som kan bruges i fremtidens kultur- og mediepolitik. $^{3}$

Jeg har i denne historiske gennemgang af hovedstromninger $i$ dansk medieforskning peget på sommetider ganske voldsomme modswtninger og dønninger $i$ et fag under tilblivelse og udvikling. Ved feks. at modstille den kritiske medieforskning og de nyere modtagerstudier har jeg bl.a. peget på to tilsyneladende meget modsatte udgangspunkter i mediefagets teoretiske og metodiske historie: det ene med stark vægt pa teksten og tekstens direkte sammenvaevning med samfundsmassige forhold, og det andet med stærk vagt på modtageren og modtagerens sociale og kulturelle kontekst. Forskellene er reelle, men der er også en anden pointe, som handler om ligheder midt i forskellighederne, og som for mig at se viser en vis pragmatisk sammenhængskraft i dansk film- og medieforskning. Det viser sig symptomatisk ved, at selv den mest ideologikritiske analyse fra 70 'erne meget ofte ud over det institutionelle og teksten laktisk havde modtageren med pa dagsordenen, ligesom den receptionsanalysen og de etnografiske studier i prak- sis faktisk viser sig at inddrage betydelige aspekter af institutionsanalyse og tekstanalyse. Det er altsả også en del af denne historie, at medieforskningen udspiller sig indenfor en triangular struktur, der med forskellig vagt og forskellige teoretiske og metodiske greb satter institution/samfund, tekst/ astetik og modtager i forhold til hinanden. Men balancen har det med at forskyde sig mellem disse tre omräder, og i perioder flytter den aktuelle forskningsdagsorden vagten fra den ene til en af de andre poler i relationen. Lige nu oplever vi en sociologisk og en kognitiv bolge der satter berettiget fokus pă to forskellige aspekter af mediekulturens teoretiske og metodiske helhed, men det er helheden, der er det afgorende - helheden af de xstetiske, sociologiske, kulturelle og psykologiske perspektiver. En teori eller metode, som havder at verden kan belyses fra kun et af disse punkter, er pă vildspor. Selvom det er vigtigt med specialiscring og sclvom ikke alle medieanalyser kan lagge lige vagt på det hele, så er trianguleringen mellem de fundamentale storrelser et afgorende must, også for en fremtidig medicforskning.

Det galder også for et fremtidigt mediefag som dannelsesfag. Det or og bliver en skandale, at et skolefag og dannelsesfag, som afspejler den nu veletablerede medievidenskab pä universitetsniveau, ikke er blevet etableret på folkeskole- og gymnasicniveau. Fremtidens mediekultur vil stille stadig storre krav til den historiske, kritiske og kreative mediekompetence i forhold til bäde de traditionelle og de nye medier - her kan man ikke nojes med begransede tilbudsfag eller små lommer iandre fag. Det er en af det nye årtusindes store udfordringer, at mediefagets videnskabelige styrke og bredde omsættes til et skolefags pædagogiske og dannelsesmassige styrke.

\section{Noter:}

1. Filmforskningen' ligger i perioden fra ca, 1930 og frem mellem det journalistiske, kritiske og akademiske og er i hoj grad knyttet til tidsskrifter, til Filmmuseet og til folkeoplysningen. Men det ex kam rakteristisk at begrebet 'Gimmagister' bliver et accepteret begreb allerede i lobet af 50 erne gennem Bjorn Rasmussens og senere I. C Lauritzens filmmagasiner på radio og tv. Hvad angår det andet pioneromräde presseforskning, sâ udkommer Pressens ärbog fra $1964 \mathrm{og}$ en af de forste akademiske boger i dansk medieforskning Niels Thomsens Paripressen (1965) er udgivet af Institut for PresseCorskning og Samtidshistorie, $\mathrm{KU}$, et institutnavn 
som dog ikke synes at have veret permanent, men antyder et tidligt forsog pâ at institutionalisere en medieforskning som presseforskning.

2. Det er for sa vidt pâfaldende, at poststrukturalisme og dekonstruktion og den ofte dermed sammenhorende psyko-semiotik ganske vist slog igennem i dansk filmm og medieforskning, men at det trods alt ikke er en markant og stark stromming. Eksempler pă poststrukturalistisk inspirerede film-\& medieanalyser lindes feks. hos Ove Christensen og Claus K. Kristiansen (1992 og 1995), hos Esben Krohn (1991) og Troels Degn Johansen (1991), og pâvirker ogsầ den feministiske flmkritik (feks. Anne Jerstev, 1989 og Vibeke Pedersen, 1995 ), men den modes of te al modgaende tendenser. Men $i$ langt de fleste tilfalde bliver en poststrukturalistisk inspiration ikke til rabiat relativisme og subjektivisme $i$ dansk filmog medieforskning. Det er måske snarere indenfor litteraturteorien i 90 erne synspunkteme slar rent igennem, jvf. Pil Dahlerup, 1991.

3. Sevom jeg i denne fremstilling har forsogt at tegne et ganske bredt portrat af hovedstromninger i dansk medieforskning, sa er der naturligvis tendenser, somjeg ikke har fot med. Err af disse tendenser er den tradition for mediepolitisk engagement, som er frembadende idansk medieforskning. Der ligger naturligvis en fare i denne tendens - en fare for at medieforskningen ender som administrativ del af det politiske system. Men hovedsagelig man mase at danske medieforskeres indsats feks i bade den forste og den anden store Mediekommission reprasenterer vasentlig clement, hor medieforskeme stiller deres viden og ekspertise til radighed for offentligheden og er med til at udforme principper og rammer for mediem og kulturpolitikken.

\section{Litteratur:}

Ang, Ien (1985): Watching Dallas. London: Methuen.

Andersen, Michael Bruun m.1. (1974): Filmanalyer. Kobenhavn: Rode Hane.

Andersen, Michael Brum \& Poulsen, Jorgen (red) (1974): Medieroctologi. Kobenhavn: Rhodos.

Bolvig, Kirsten, m.1. (1971); Sandags-B.T. Rappon om an suces. Kobenhavn: Gyldendal.

Bondebjerg, Ib (1976-78): Proletarish offonthyhed 1-2. Kabenhavn: Medusa.

Bondebjerg, Ib (1988): 'Kritisk teori, astetik og receptionsforskning? In: Mediakulur, nr. 7, 1988.

Bondebjerg, Ib (1989): 'Medier og postmodemisme'. In: Kosmorama, nr. 189.

Bondebjerg, $\mathrm{B}$ (1993): Elektrutske fiktoner. TV som fortellende wedie. Kobenhavn: Borgen.

Bondebjerg, Ib (ed) (1999): Mowng Images, Culture \& The Mind. Luton: University of Luton Press.

Bordwell, David (1985): Narration in the Fiction Fitm. Madison: University of Wisconsin Press.

Brink Lund, Anker (1976). Magton ozer DR Arhus: Publimus.
Bogh Andersem, Peter (1990): A Theoy of Computer Semothes. Oxford: Oxford University Press.

Christensen, Ove \& Claus K. Kristiansen (1992): Det hemmelige og det hellige i Twin Peaks. In: $K G K$, nr. 71.

Christensen, Ove \& Glaus K. Kristiansen (1995): Porten til Riget' In: Eva Jorhold (ed): Ind i filmen. Kobenhavn: Medusa.

Dines Johansen, Jargen (1993): Dialogic Semiosis. Bloom mington: Idinana Unioversity Press.

Bruhn Jensen Klaus (1986): Making Sense of the Mews. Ar. hus: Arhus University Press.

Bruhn Jensen, Klaus(1987): Seomes Towvis. Kobenhavn: DR-forskningstapprot nr. 2B/87.

Bruhn Jensen, Klaus (1988): 'Fire argumenter for at afskaffe den empiriske receptionsforskning. In: Mediekuluer, nr. 7 .

Bruhn Jensen, Klaus (1995): The Socid Semwotes of Mass Communication. London: Sage.

BruhnJensen, Klaus, m.1. (1996-97): Dansk Mediehtsone 1-3. Kobenhavn: Samleren.

Dahlerup, Pil (1991): Deknshuktion. Kobenhavn. Gyldendal.

Degn Johansen, Troels: 'Mise en obscene. Om Epidemick eller wswerten pá iscenesatterens svededug. In: Selvens 91.

Drotner, Kirsten (1977): Drengemagasiner-Magasindrenge. Grena: GMT.

Drotner, Kirsten (1988): English Children and their Magaz:ner 1751-1945 New Haven and London: Yale University Press.

Drotner, Kinsten(1991): At skabe sig wolw. Kobenhavn: Gyldendal.

Drotner, Kirsten (1993): 'Medieemografiske problemstillinger' In: Modickultur, nr. 21.

Fausing, Bent(1978): Fotchatonformer. Asteth og medier under fascismenog i soctalstaten. Kobenhavn: Gyldendal.

Fausing, Bent \& Larsen, Peter(1980): Wisuel Kommunikaton 1-2. Kobenhavm: Medusa.

Finnemann, Niels Ole (1993): Tanke, spog og maskine. Kobenhaxn: Akademisk forlag.

Hish, Stanley (1980): Is There a Text in this Class? Cambridge Mass.: Harvard University Press.

Fiske, John (1978): Fjensynets sprog. Kobenhavn: Arnold Busck.

Fiske, John (1987): Teletsion Culture. London \& New York: Methuen.

Fjord Jensen, Johan, m.1. (1984-85): Dansh Literahuhistorie 1-9. Kobenhavn: Gyldendal

Gall Jorgensen, Keld (ed) (1997): Amendt Semiatik Kobenhavn: Akademisk forlag

Giersing, Morten(1982): TV : USA. Kobenhavn: Gylden dal.

Giddens, Anthony (1984): The Constiution of Society. Cam bridge: Polity Press.

Giddens, Anthony (1992): Modeminy and Sef-identiy. Cambridge: Polity Press.

Golman, Erwin (1992): Wore rollespil i hrendagen. Kobenhavn: Reitzel 
Grodal, Torben (1994)" 'Kognitiv medieanalyse" In: Medickultur, nr. 22.

Grodal, Torben(1997): Moving Pistures. Oxford: Oxford University Press.

Hall, Stuart (1980): 'Encoding-Decoding. In Hall (ed. 1980): Culure, Media, Languge London: Hutchinson

Hjarvard, Stig \& Hemik Sondergaard (1988): Nersyn pa fjemsyn. Kobenhavn: C.A. Reitzel.

Harvard, Stig (1994): "IndLedning". In: Mediekultur, nr. 22.

Harvard, Stig(1995): Internationale TVmoheder. Kobenhavn: Akademisk forlag.

Hjarvard, Stig(1999): TV-ryheder i honkurrence. Kobenhavn: Samtidskitteratur.

Hjort, Anne (1984): Nar kwinder ser th om medoforkning og reception. Kobenhavns Universitet: Sknfter fra Institut for Litteraturvidenskab.

Jensen, Thorkil B. og Jens Pedersen(1973): Billdmedier. Kobenhavn: Gyldendal.

Jensen, Poul (1970): Presse, penge G polihk. 1839-48. Kobenhavn: G.E. Gad.

Jorgensen, John Chr. (1994), Det Danske anmelderishistorie. Viborg: Fisker \& Schou.

Jerslev, Ame (1989): 'Rejsen til det morke kontinent. Om Bhe Votwet? In: Ke $\mathrm{K}, \mathrm{nt} .78$.

Kjorup, Soren(1975): Filmsemiologi. Kobenhavn: Berlingske.

Kjorup, Soren (1994): Semionik og retorik.' In: Mediekul tur, $\mathrm{nr} .22$

Krohn, Esben (1991): 'Gravrosten. En refleksion over The Element of Crime. In Selown 91.

Larsen, Peter (1974): Analyse âP TV-avisen.'In: Andersen, Michael Bruun \& Poulsen, Jorgen (red) (1974): Mediesociolog? Kobenhavn: Rhodos.

Larsen, Peter (1974a): Mc Cloud som ideologisk og industriel produkt.' In: Andersen, Michael Bruun \& Poul sen, Jorgen (red) (1974): Mediespciologi. Kobenhavn: Rhodos.

Lauridsen, Palle Schantz (1984): Chrithan Metz' fumsemologi. Kobvenhavns Universitet. Sekvens Sarrake.

Lauridsen, Palle Schantz (1990): Barhes og flmen. Kobenhavns Universitet. Sekvens Sarrakke.

Merton, Rober K (1957): SocialTheory and Social Structure. New York.

Meyrowitz, Joshua (1985): No Sense of Place. New York: Oxford University Press.

Morley, David (1980): The Natonuide Aadience. London: BFI.

Mortensen, Frands(1972): Kommumationshilisk analyse of 22-Radiouvisen. Grenâ: GMT.

Mortensen, Frands, m.11. (1977): Kke et ond omytringsfihed. Arhus: Modrryk.
Mortensen, Frands, m.11. (1990): Mediehaindbogen. Koben havn: Gyldendal

Moller, Hannc, m.1. (1972): Udsigtenfra det kvindelige Uniwers. En anabre af Eia. Kobenhavn: Rode Hane.

Olivarius, m.A. (red) (1976). Masehommunikaton introduttion tilet underovmingsomride. Kobenhavn: Danshla rerforeningen.

Pedersen, Vibeke (1995): Kunden som ikon. Kobenhavn: Borgen.

Pittelkow, Ralf(1985): 'Seernes tvavis' In: Ralf Pittelkow (red): Analyser of T V. Kobenhavm: Medusa.

Pittelkow, Rail \& Elsc Fabricius Jensen (1986): Det uhendte publikum. Koberhavn: C.A. Reitzel.

Poulsen, Jorgen (1996): Dagbladsproyektet 1-6. RUC: Kommunikationsuyddannelsen.

Poulsen, Jorgen: Moiske lasme 1-4. RUC. Joumalistik

Povsen, Karen Klitgaard(1999): Beverly Hills 90210 soaps ironiag danshe unge. Arhus: Forlaget $\mathrm{K}$ lim.

Prehn, Ole (1981): "TV-avisen som underholdningsserie" In: Mortensen, m.1.: Chderholdning i TV. Kobenhavn: Arnold Busck.

Seeberg Fris, m.n. (red) (1976): TV-analyse Tervog metode til medieundervisning og krik. Kobenhavn: Dansklarerforeningen.

Schroder, Kim (1988): 'Oplevelsens kvalite: In: Mediesulus, nu. 7 .

Sondergaard, Henrik (1994): DR t tr-konkurenens tidsalder. Kebenhavn: Samfundslitteratur.

Thompson, John B. (1988): The Media and Modemity. Cambridge: Polity Press.

Thompson, Kristin (1988); Braking the Glass Amor. Prin* ceton: Princeton University Press.

Thomsen, Nicls (1965): Partipressen. Kobenhavr: Institut for Presseforskning og samtidshistorie. KU.

Thomsen, Niels (1972): Dagbladshonkurnencen 1870-19701-2.

Troeken, Anders (red) (1980): Levende billeder af Danmark. Kobenhavn: Medusa.

Tof, Jens(1985): Filmsprog, subjekt og samfund. Kobenhavns Universitet: Sekvens Serrakke.

Tufte, Birgitte(1995): Shole og medier. Kobenhavn: Akademisk forlag.

Orvad Andersen, Lissie, m.1. (1973): Tegneserier. En ekspomsionshistorie. Grena: GMT.

Ib Bondebjerg er professor ved Institut for Filmog medievidenskab, Københavns Universitet 


\title{
Ny dansk filmforskning: En oversigt
}

\author{
Af Peter Schepelern
}

\begin{abstract}
I denne artikel giver Peler Schepelem en oversigt over dansk filmforskning. Artiklen omtaler de forskellige forskningsmilger, opridser de leoreliske hovedtendenser og nooner de analytiske og historiske bidrag, som dansk filmforskning har leveret i de seneste ti år. Artiklen kan således leses som en kommenteret bibliografi wil wy dansk fim forskning.
\end{abstract}

\section{Traditioner}

Filmforskningens traditioner i Danmark er form holdsvis spinkle. Hvis vi tager det i fast motion kan man notere, at de ca. begynder med Urban Gads Filmen. Dens Midler og Maal (1919), en statelig udgivelse på Gyldendal, men mest en oversigt over filmproduktionens praktiske omstandigheder. I $1936 \mathrm{kom}$ to unge filmfreaks, Theodor Christensen og Karl Roos, med deres svart tilgangelige bog Film. Det var Danmarkshistoriens forste akademisk pragede forsøg på en sondering af filmen, og selv om magistrene Bjorn Rasmussen og I.C. Lauritzen i 50 'erne kom med gode popularintroduktioner, var min egen magisterafhandling, Den fortallendef flm fra 1972 (magisterafhandling), faktisk kun den anden filmvidenskabelige bog i kongeriget. Men da var film jo ogsă omsider blevet etableret som akademisk disciplin (1967). Fagets tidlige hovedkrafter, amanuenserne Marguerite Engberg, Bjorn Rasmussen og Martin Drouzy prasenterede i deres egen produktion tre karakteristiske tilgange til filmforskningen. Bjorn Rasmussen personificerede begrebet filmmagister, selv orn han ikke var magister i film, men i nordisk litteratur. Han var den eneste forbindelse mellem filmen og det akademiske, som offentigheden dengang havde fantasi til at forestille sig. Rasmussen, der røg store cigarer, var den pertentlige registrator og leksikograf, som utratteligt jagtede alle svarene på filmens Hvem? og Hvad? og Hvor? (Filmens Hvem Hoad Hvor [-V, 1968-70). Marguerite Engberg stod som den rationelle udforsker af historiske forhold i en specifik epoke (med Dansk Stumfilm I-II, 1977 som hovedvarket). Marguerites kup var tydningen af de mystiske tal pa stumfilmstrimlerne. Hun fandt frem til en gammel dame, der havde arbejdet i la- boratorierne dengang og kunne knokke koderne. Martin Drouzy var den visionære fortolker; han lod sig rive med - og rev os andre med. Men da Drouzy mente at kunne udtale sig om Dreyers mors »ulmende erotiske drifter $p a ̊$ to svenske sommernætter i henholdswis 1888 og i 1890 (Canl Th. Dreyer fodt Nilsson I-II, 1982), folte man nok, at han overskred sin videnskabelige kompetence.

Sådan begyndte det altså. Her stod den danske filmforsknings vugge. Siden er det blevet et mere omfattende, men ikke mere broget felt. Skal man danne sig et overblik over filmforskningens situation her en menneskealder senere, må man orientere sig i en rekke forskellige forskningsmiljøer.

\section{Forskningsmiljøer}

Der er den officielle akademiske forskning med universiteteme som udgangspunkt. Kobenhavn har det storste antal forskerstillinger, men filmvidenskaben bedrives også fra ofte mere medicvidenskabelige tilgange i Ârhus, Odense, Aalborg og Roskilde. Hertil kommer også den akademiske fllmforskning, der lojlighedsvis finder sted ved andre institutter, bl.a. ved Nordisk, ved Litteraturvidenskab, ved Kunsthistorie og ved Historie. Film- (og medie) tidsskrifter med tilknytning til de akademiske miljoer er Kobenhavns Sekvens og Arhus' hovedsagelig engelsksprogede p.o.\%.

Der er forskning, som foregår i arkiver, forst og fremmest Det Danske Filminstitut/Museum \& Cinematek. Museet og arkivet er selvsagt helt cenm trale for den akademiske forskning, men Musect har også i de senere ăr selv engageret sig mere direkte i forskning, bl.a. opbygges der nu en stor database over hele den danske film (under ledelse af Thomas C. Christensen og Ebbe Villadsen), delvis 